\title{
Aestuariibacter salexigens gen. nov., sp. nov. and Aestuariibacter halophilus sp. nov., isolated from tidal flat sediment, and emended description of Alteromonas macleodii
}

\author{
Hana Yi, ${ }^{1}$ Kyung Sook Bae ${ }^{2}$ and Jongsik Chun ${ }^{1}$ \\ ${ }^{1}$ School of Biological Sciences, Seoul National University, 56-1 Shillim-dong, Kwanak-gu, \\ Seoul 151-742, Republic of Korea \\ ${ }^{2}$ Korean Collection for Type Cultures, Korea Research Institute of Bioscience and \\ Biotechnology, Yusung, PO Box 115, Taejon 305-600, Republic of Korea
}

\begin{abstract}
Two strictly aerobic, halophilic strains of the $\gamma$-Proteobacteria, designated $\mathrm{JC}_{2042^{\top}}$ and $\mathrm{JC} 2043^{\top}$, were obtained from a sediment sample of getbol, the Korean tidal flat. Comparative 16S rDNA sequence studies revealed that the test strains were related most closely to the type strains of the genera Alteromonas (93.5-95.5\%) and Glaciecola (91.1-93.3\%). Phylogenetic analyses demonstrated that strains $\mathrm{JC}_{2} 2042^{\top}$ and $\mathrm{JC} 2043^{\top}$ formed a distinct monophyletic clade within the family Alteromonadaceae and clustered distantly with the genera Alteromonas and Glaciecola. Physiological, biochemical and chemotaxonomic data also indicated that the two getbol isolates were significantly different from members of these two genera and others with validly published names. Cells were rod-shaped and motile with a polar flagellum. The major isoprenoid quinone was $Q 8$. The predominant cellular fatty acids were $C_{16: 0}, C_{18: 1} \omega 7 c$ and a mixture of $C_{16: 1} \omega 7 c$ and iso- $\mathrm{C}_{15: 0}$ 2-OH. DNA G $+\mathrm{C}$ contents were $48-54 \mathrm{~mol} \%$. On the basis of this polyphasic study, Aestuariibacter gen. nov. is proposed with two novel species, Aestuariibacter salexigens sp. nov. (type strain, $\mathrm{JC} 2042^{\top}=\mathrm{IMSNU} 14006^{\top}=\mathrm{KCTC} 12042^{\top}=\mathrm{DSM} 15300^{\top}$ ) and Aestuariibacter halophilus sp. nov. (type strain, JC2043 ${ }^{\top}=\mathrm{IMSNU} 14007^{\top}=\mathrm{KCTC}$ $12043^{\top}=$ DSM $\left.15266^{\top}\right)$. Aestuariibacter salexigens is the type species of the genus. In addition, an emended description of Alteromonas macleodii is proposed.
\end{abstract}

\section{INTRODUCTION}

The family Alteromonadaceae Ivanova \& Mikhailov 2001 encompasses the genera Alteromonas, Pseudoalteromonas, Idiomarina and Colwellia. The genera Glaciecola Bowman et al. 1998 and Thalassomonas Macián et al. 2001 are phylogenetically closely related to Alteromonas macleodii and also should be regarded as members of this family. All strains of these genera are widespread inhabitants of marine environments and have been isolated from diverse marine sources. In this study, two bacterial strains that were isolated from the sediment of getbol (the Korean tidal flat) were the subject of a taxonomic investigation. On the basis of polyphasic evidence, the test strains formed a novel genus in the family Alteromonadaceae, for which the name Aestuariibacter gen. nov. is proposed.

Published online ahead of print on 13 October 2003 as DOI 10.1099/ ijs.0.02798-0.

The GenBank/EMBL/DDBJ accession numbers for the 16S rDNA sequences of strains $\mathrm{JC} 2042^{\top}$ and $\mathrm{JC} 2043^{\top}$ are AY207502 and AY207503, respectively.

\section{METHODS}

Bacterial strains. Test strains were isolated from a sediment sample of the getbol of Ganghwa Island, Korea $\left(37^{\circ} 35^{\prime} 31 \cdot 9^{\prime \prime} \mathrm{N}\right.$, $126^{\circ} 27^{\prime} 24 \cdot 5^{\prime \prime}$ E) on August 31, 2002. The sample was diluted with sterilized artificial sea water (ASW; Lyman \& Fleming, 1940), spread onto a plate that contained marine agar 2216 (MA; Difco) and MR2A [R2A (Difco) supplemented with artificial sea salts (Sigma)] and incubated at $25^{\circ} \mathrm{C}$ for 3 weeks. Strains JC2042 ${ }^{\mathrm{T}}$ and $\mathrm{JC} 2043^{\mathrm{T}}$ were isolated on MA and MR2A, respectively, and were cultured routinely on MA at $30{ }^{\circ} \mathrm{C}$. Alteromonas macleodii LMG $2843^{\mathrm{T}}$ and Glaciecola punicea DSM $14233^{\mathrm{T}}$ were used as reference strains and were grown on $\mathrm{MA}$ at 30 and $10^{\circ} \mathrm{C}$, respectively.

Molecular systematics. Bacterial DNA preparation and PCR amplification and sequencing of $16 \mathrm{~S}$ rDNA were carried out as described previously (Chun \& Goodfellow, 1995). The resultant sequences of strains $\mathrm{JC} 2042^{\mathrm{T}}$ and $\mathrm{JC} 2043^{\mathrm{T}}$ were aligned manually against sequences obtained from GenBank. Phylogenetic trees were inferred by using the Fitch-Margoliash (Fitch \& Margoliash, 1967), maximum-likelihood (Felsenstein, 1993), maximum-parsimony (Fitch, 1971) and neighbour-joining (Saitou \& Nei, 1987) methods. Evolutionary distance matrices were generated according to Jukes \& Cantor (1969). Resultant tree topologies were evaluated by bootstrap analyses (Felsenstein, 1985) based on 1000 resamplings. Alignment 
and phylogenetic analyses were carried out by using the PHYDIT program (available at http://plaza.snu.ac.kr/ jchun/phydit/) and PAUP 4.0 (Swofford, 1998), as described previously (Chun et al., 2000).

Morphology and physiological properties. The methods, as well as compositions of media used in this study, have been described previously (Yi et al., 2003). Only additional methods or significant modifications are given below.

Carbon source utilization was tested on basal medium (BM; Baumann et al., 1972) and BM supplemented with $0 \cdot 01$ or $0 \cdot 1 \%$ yeast extract. Oxidation or fermentation of carbohydrates (D-glucose, $\mathrm{N}$-acetylglucosamine and inulin) was examined by using fermentation media (Baumann et al., 1971) and modified oxidation-fermentation medium (MOF; Leifson, 1963). Strips of the API ZYM and 20NE kits (bioMérieux) were inoculated with cell suspensions in halfstrength ASW and incubated at $30^{\circ} \mathrm{C}$, except for G. punicea ACAM $611^{\mathrm{T}}$, for which tests were done at both 10 and $30^{\circ} \mathrm{C}$. Catalase reaction was determined by $3 \%(\mathrm{v} / \mathrm{v})$ hydrogen peroxide. Specific component requirements for ASW $\left(\mathrm{NaCl}, 23.5 \mathrm{~g} ; \mathrm{MgCl}_{2}, 4.9 \mathrm{~g} ; \mathrm{Na}_{2} \mathrm{SO}_{4}, 3.9 \mathrm{~g}\right.$; $\mathrm{CaCl}_{2} .2 \mathrm{H}_{2} \mathrm{O}, 1.1 \mathrm{~g} ; \mathrm{KCl}, 0.66 \mathrm{~g} ; \mathrm{NaHCO}_{3}, 0.19 \mathrm{~g} ; \mathrm{KBr}, 0.096 \mathrm{~g}$; $\mathrm{H}_{3} \mathrm{BO}_{3}, 0.026 \mathrm{~g} ; \mathrm{SrCl}_{2}, 0.024 \mathrm{~g}$; NaF, 0.003 g; distilled water, 1 l) were tested by using synthetic MA (10 g Bacto peptone, $2 \mathrm{~g}$ yeast extract, $0 \cdot 2 \mathrm{~g}$ ferric citrate and $15 \mathrm{~g}$ Bacto agar in 11 distilled water) supplemented with various combination of artificial sea salts. Growth in synthetic media was determined after 3 days at $30^{\circ} \mathrm{C}$.

Chemotaxonomy. Chemotaxonomic characteristics were determined from cells grown at $30^{\circ} \mathrm{C}$ for 2 days on MA or in marine broth 2216 (MB; Difco). Analysis of fatty acid methyl esters was performed by GLC according to the instructions of the Microbial Identification system (MIDI). Isoprenoid quinones were isolated according to Minnikin et al. (1984) and analysed by HPLC (Waters) as described by Collins (1985). DNA G + C content was determined by HPLC of deoxyribonucleosides as described by Mesbah et al. (1989), using a reverse-phase column (Supelcosil LC-18-S; Supelco).

\section{RESULTS AND DISCUSSION}

\section{Phylogenetic analysis}

Almost-complete 16S rDNA sequences of strains JC2042 ${ }^{\mathrm{T}}$ (1439 bp) and JC2043 ${ }^{\mathrm{T}}$ (1434 bp) were obtained and used for an initial BLAST search against sequences in GenBank.
The result clearly indicated that the getbol isolates belonged to the $\gamma$-Proteobacteria. The newly determined sequences were then aligned manually against representatives of the $\gamma$-Proteobacteria, based on bacterial $16 \mathrm{~S}$ rRNA secondary structure. Regions available for all sequences were the domains used to construct the phylogenetic tree (positions 35-1459 of the Escherichia coli 16S rDNA sequence), excluding positions that were likely to show ambiguous alignment (positions 75-95, 204-213, 841-846, 1132-1141 and 1448-1454). Sequence similarity between strains $\mathrm{JC} 2042^{\mathrm{T}}$ and $\mathrm{JC} 2043^{\mathrm{T}}$ was $96.6 \%$, which indicated that these strains belonged to different species (Stackebrandt \& Goebel, 1994). The highest similarity values of our isolates to species with validly published names were as follows: Alteromonas marina $\mathrm{SW}-47^{\mathrm{T}}(93.8 \%)$, Alteromonas macleodii DSM $6062^{\mathrm{T}}(93.5 \%)$, G. punicea ACAM $611^{\mathrm{T}}$ $(93 \cdot 3 \%)$ and Glaciecola pallidula ACAM $615^{\mathrm{T}}(91 \cdot 1 \%)$ for strain $\mathrm{JC} 2042^{\mathrm{T}}$, and Alteromonas marina SW $-47^{\mathrm{T}}(95 \cdot 5 \%)$, Alteromonas macleodii DSM $6062^{\mathrm{T}}(95 \cdot 3 \%)$, G. pallidula $\operatorname{ACAM} 615^{\mathrm{T}}(92 \cdot 6 \%)$ and G. punicea ACAM $611^{\mathrm{T}}(92 \cdot 2 \%)$ for strain $\mathrm{JC}^{2} 243^{\mathrm{T}}$.

This relationship between our isolates and other genera was also highlighted in the phylogenetic trees, as shown in Fig. 1. Strains JC2042 ${ }^{\mathrm{T}}$ and JC2043 ${ }^{\mathrm{T}}$ formed a monophyletic clade with a bootstrap value of $77 \%$ that was supported by all tree-making methods employed in this study. The genus Alteromonas also formed a strong monophyletic clade (bootstrap value of $100 \%$ ) and was recovered as a sister group to the monophyletic clade that contained the getbol isolates. Members of the genera Alteromonas and Glaciecola and the two test strains were recovered in a significant monophyletic clade with $100 \%$ bootstrap support; the branch pattern within the clade was identical in all phylogenetic trees. On the basis of sequence similarities and phylogenetic analysis, it is clear that our isolates cannot be assigned to either Alteromonas or Glaciecola, and should merit a novel genus in the family Alteromonadaceae.

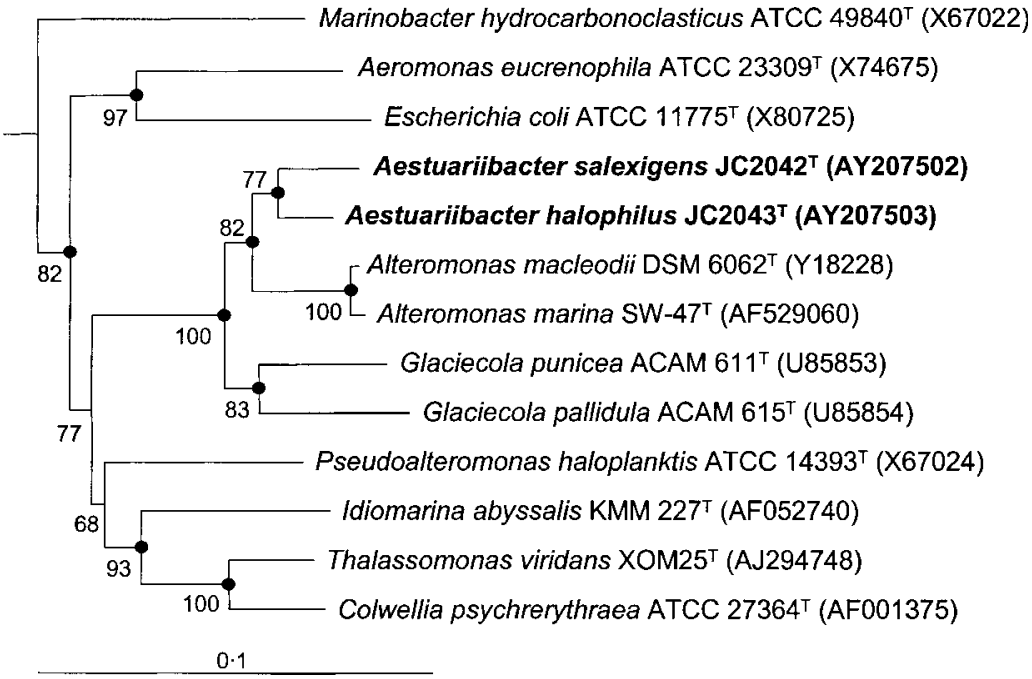

Fig. 1. Phylogenetic relationship of strains $\mathrm{JC} 2042^{\top}$ and $\mathrm{JC} 2043^{\top}$ and related species within the $\gamma$-Proteobacteria, based on $16 \mathrm{~S}$ rDNA sequences. The tree was created by using the neighbour-joining method; percentage numbers at nodes are levels of bootstrap support from 1000 resampled datasets. Solid circles indicate that the corresponding nodes (groupings) were also recovered in Fitch-Margoliash, maximumlikelihood and maximum-parsimony trees. Helicobacter pylori ATCC $43504^{\top}$ (GenBank accession no. U01330) was used as the outgroup. Bar, $0 \cdot 1$ nucleotide substitution per position. 


\section{Culture and growth conditions}

Cultural characteristics were studied by using several bacteriological growth media. Abundant growth was observed on MA, CSY-3 (Sawabe et al., 1998) and SMM (Shioi's Marine medium; Shiba, 1981). Both strains grew on MA at pH 6-11; optimal growth occurred at $\mathrm{pH}$ 7-8. Strain JC2042 ${ }^{\mathrm{T}}$ grew at $20-40{ }^{\circ} \mathrm{C}$ and the optimum was $35^{\circ} \mathrm{C}$. Strain $\mathrm{JC} 2043^{\mathrm{T}}$ grew at $15-40^{\circ} \mathrm{C}$ and the optimum was $40^{\circ} \mathrm{C}$. These two strains were common in strict halophilicity, but exhibited slightly different requirements of sea salts. Strain JC2043 ${ }^{\mathrm{T}}$ showed growth on $0 \cdot 5-10 \%$ (w/v) artificial sea salts (Sigma)-based media (the optimum being $2-3 \%$ sea salts) and showed less abundant growth on $1-8 \%(\mathrm{w} / \mathrm{v}) \mathrm{NaCl}$-containing media (the optimum being $5-6 \% \mathrm{NaCl}$ ). Similarly, strain $\mathrm{JC} 2042^{\mathrm{T}}$ required $1-10 \%(\mathrm{w} / \mathrm{v})$ artificial sea salts-based media for growth (the optimum being 2-6\% sea salts), but completely failed to grow on modified CSY-3 that contained $0-15 \%(\mathrm{w} / \mathrm{v})$ $\mathrm{NaCl}$ alone. Strain $\mathrm{JC}_{2042^{\mathrm{T}}}$ showed no growth when $\mathrm{NaCl}$ was not added to synthetic MA and very weak growth when any of several sea salts components, namely $\mathrm{MgCl}_{2}$, $\mathrm{NaHCO}_{3}, \mathrm{H}_{3} \mathrm{BO}_{3}$ and $\mathrm{NaF}$, was omitted. However, growth of strain $\mathrm{JC} 2043^{\mathrm{T}}$ only decreased a little without $\mathrm{NaCl}$, $\mathrm{H}_{3} \mathrm{BO}_{3}$ or NaF. No growth was detected under anaerobic conditions, created by a GasPack system (BBL). Strain JC2042 $2^{\mathrm{T}}$ showed a marked loss of viability within 7 days on $\mathrm{MA}$ at $30^{\circ} \mathrm{C}$.

\section{Morphological properties}

Cellular and colonial morphologies of cells grown on MA at $30^{\circ} \mathrm{C}$ for 2 days were observed. Colonies of both strains did not swarm or luminesce on the agar media tested and spore formation was not observed. Cellular and colonial morphologies are given in the species descriptions.

\section{Physiological and biochemical properties}

Physiological and biochemical properties of strains JC2042 ${ }^{\mathrm{T}}$ and $\mathrm{JC} 2043^{\mathrm{T}}$, as well as some other characteristics, are given in the genus and species descriptions. A summary of the major differential properties between the test strains and phylogenetically related species is given in Table 1 .

Several properties of A. macleodii LMG $2843^{\mathrm{T}}$ were discordant with previous results that were reported by others (Baumann et al., 1972, 1984; Gauthier et al., 1995). In contrast to the results described by Gauthier et al. (1995), A. macleodii LMG $2843^{\mathrm{T}}$ showed an obvious catalasepositive reaction. In addition, D-ribose, L-arginine and succinate were utilized as sole carbon sources under the same test conditions as in the previous study (Baumann et al., 1972). Finally, A. macleodii LMG $2843^{\mathrm{T}}$, together with strain JC2043 ${ }^{\mathrm{T}}$, showed slightly fermentative reactions for glucose and $\mathrm{N}$-acetylglucosamine in MOF medium, which may result from residual oxygen in this medium. Based on these differences, an emended description for A. macleodii is given later.

\section{Chemotaxonomic characteristics}

Cellular fatty acid profiles of the test strains are given in Table 2 . These fatty acid compositions are not only similar to each other, but also to those of the genus Alteromonas. As reported for other members of the family Alteromonadaceae (Ivanova \& Mikhailov, 2001), Q8 was the predominant isoprenoid quinone in both strains. The DNA $\mathrm{G}+\mathrm{C}$ contents of strains JC2042 ${ }^{\mathrm{T}}$ and JC2043 ${ }^{\mathrm{T}}$ were 48 and $54 \mathrm{~mol} \%$, respectively.

\section{Taxonomic conclusions}

Polyphasic analyses demonstrate that the two getbol isolates belong to a coherent taxon and represent a novel genus within the family Alteromonadaceae. Phenotypic data also indicate that strains JC2042 ${ }^{\mathrm{T}}$ and JC2043 ${ }^{\mathrm{T}}$ are not affiliated closely with any previously described genus and are sufficiently different from each other to be recognized as separate species (Table 1). Strain JC2043 ${ }^{\mathrm{T}}$ shows Alteromonas-like phenotypic properties in colonial morphology, lecithinase, acid phosphatase, utilization of D-glucose as sole carbon source and relatively high $16 \mathrm{~S}$ rDNA sequence similarity to members of the genus Alteromonas $(95 \cdot 1-95 \cdot 5 \%)$. However, monophyly of the two getbol isolates is not only strongly supported by all tree-inferring methods, but also by several phenotypic characteristics, namely sea salts requirement, nitrate reduction, alginase, $\beta$-galactosidase, valine arylamidase and utilization of D-cellobiose, D-fructose, D-raffinose, D-salicin, D-xylose and lactose (Table 1). It is therefore proposed that the two getbol isolates should be assigned to a novel genus in the family Alteromonadaceae, Aestuariibacter gen. nov., as Aestuariibacter salexigens sp. nov. for strain $\mathrm{JC}^{2} 042^{\mathrm{T}}$ and Aestuariibacter halophilus sp. nov. for strain $\mathrm{JC} 2043^{\mathrm{T}}$.

\section{Description of Aestuariibacter gen. nov.}

Aestuariibacter (Aes.tu.ar.i.i.bac'ter. L. neut. n. aestuarium - $i$ tidal flat; N.L. masc. n. bacter rod; N.L. masc. n. Aestuariibacter rod-shaped bacterium from tidal flat).

Gram-negative and oxidase- and catalase-positive. Strictly aerobic, chemoheterotrophic, halophilic, mesophilic and neutrophilic. Cells are rod-shaped and motile with a polar flagellum. Abundant growth occurs on MA, CSY-3 and SMM media. Spores are not formed. Major isoprenoid quinone is Q8. Predominant cellular fatty acids are $\mathrm{C}_{16: 0}$, $\mathrm{C}_{18: 1} \omega 7 c$ and a mixture of $\mathrm{C}_{16: 1} \omega 7 c$ and iso- $\mathrm{C}_{15: 0} 2-\mathrm{OH}$. DNA G $+\mathrm{C}$ content is $48-54 \mathrm{~mol} \%$. Phylogenetically, the genus belongs to the family Alteromonadaceae and currently contains two species. The type species is Aestuariibacter salexigens.

\section{Description of Aestuariibacter salexigens sp. nov.}

Aestuariibacter salexigens (sa.lex'i.gens. L. n. sal salis salt, sea water; L. v. exigo to demand; N.L. part. adj. salexigens sea water-demanding). 
Table 1. Characteristics that differentiate strains $J C 2042^{\top}$ and $J C 2043^{\top}$ from phylogenetically related species

Strains: 1, JC2042 ${ }^{\mathrm{T}}$; 2, JC2043 ${ }^{\mathrm{T}}$; 3, Alteromonas macleodii LMG $2843^{\mathrm{T}} ; 4$, Alteromonas marina SW $-47^{\mathrm{T}}$; 5, G. punicea ACAM $611^{\mathrm{T}}$; 6, G. pallidula ACAM $615^{\mathrm{T}}$. Data from this and earlier studies (Baumann et al., 1972, 1984; Bowman et al., 1998; Gauthier et al., 1995; Mikhailov et al., 2002; Yoon et al., 2003). + , Positive reaction; -, negative reaction; W, weakly positive; ND, no data available; NG, no growth.

\begin{tabular}{|c|c|c|c|c|c|c|}
\hline Characteristic & 1 & 2 & 3 & 4 & 5 & 6 \\
\hline Pigment & None & None & None & None & Pink & Pink \\
\hline Sea salts requirement & + & + & - & - & + & + \\
\hline Nitrate reduction & + & + & - & - & - & - \\
\hline Alginase & - & - & + & ND & ND & ND \\
\hline Amylase & + & + & + & + & - & + \\
\hline$\beta$-Galactosidase & - & - & + & ND & + & + \\
\hline Caseinase & - & + & - & + & - & - \\
\hline DNase & + & + & NG & ND & - & - \\
\hline Aesculinase & + & + & + & + & + & - \\
\hline Gelatinase & + & + & + & + & - & - \\
\hline Lecithinase & - & + & + & $\mathrm{ND}$ & - & - \\
\hline Tweenase & + & + & + & + & - & + \\
\hline \multicolumn{7}{|l|}{ Utilization of: } \\
\hline Acetate & + & + & + & + & - & + \\
\hline D-Cellobiose & - & - & + & $\mathrm{ND}$ & - & - \\
\hline D-Fructose & - & - & + & + & - & - \\
\hline D-Galactose & $\mathrm{W}$ & - & + & + & - & - \\
\hline D-Glucose & - & + & + & ND & - & - \\
\hline D-Raffinose & - & - & + & $\mathrm{ND}$ & - & - \\
\hline D-Salicin & - & - & + & ND & ND & ND \\
\hline D-Sorbitol & $\mathrm{W}$ & - & - & - & - & - \\
\hline D-Xylose & - & - & + & $\mathrm{ND}$ & - & - \\
\hline Ethanol & $\mathrm{W}$ & - & + & $\mathrm{ND}$ & ND & ND \\
\hline Glycine & + & - & + & $\mathrm{ND}$ & ND & ND \\
\hline Inulin & + & - & - & $\mathrm{ND}$ & ND & ND \\
\hline Lactose & - & - & + & + & - & - \\
\hline L-Lysine & $\mathrm{W}$ & - & - & ND & ND & ND \\
\hline L-Ornithine & + & - & - & ND & - & - \\
\hline$N$-Acetylglucosamine & + & + & + & ND & - & - \\
\hline Succinate & $\mathrm{W}$ & - & $+^{\star}$ & - & + & - \\
\hline Sucrose & - & + & + & + & - & - \\
\hline DNA G $+\mathrm{C}$ content $(\mathrm{mol} \%)$ & 48 & 54 & $45-46$ & 45 & 44 & 40 \\
\hline \multicolumn{7}{|c|}{ Major fatty acid composition (\%): } \\
\hline $\mathrm{C}_{16: 1} \omega 7 c /$ iso $-\mathrm{C}_{15: 0} 2-\mathrm{OH}$ & $27 \cdot 2$ & $32 \cdot 5$ & $34 \cdot 6$ & $28 \cdot 5$ & $60 \cdot 7$ & $54 \cdot 2$ \\
\hline $\mathrm{C}_{16: 0}$ & $15 \cdot 8$ & $23 \cdot 9$ & $25 \cdot 0$ & $21 \cdot 2$ & $10 \cdot 0$ & $9 \cdot 4$ \\
\hline $\mathrm{C}_{18: 1} \omega 7 c$ & $14 \cdot 0$ & $11 \cdot 1$ & $9 \cdot 4$ & $11 \cdot 8$ & $16 \cdot 3$ & $12 \cdot 6$ \\
\hline \multicolumn{7}{|l|}{ API ZYM: } \\
\hline Esterase lipase (C8) & + & + & + & + & - & ND \\
\hline Valine arylamidase & - & - & + & - & - & ND \\
\hline Trypsin & + & + & - & - & - & ND \\
\hline Acid phosphatase & - & + & + & + & - & ND \\
\hline
\end{tabular}

${ }^{\star}$ Difference between the results of this study and previously reported data (Baumann et al., 1984; Gauthier et al., 1995).

Cells are approximately $1 \cdot 0-1 \cdot 8 \mu \mathrm{m}$ long and $0 \cdot 4-0 \cdot 6 \mu \mathrm{m}$ wide. Optimal growth is observed at $35^{\circ} \mathrm{C}$, pH 7-8 and $2-6 \%$ artificial sea salts. Colonies are circular, raised, entirely margined, brittle, rough, opaque and white on MA and hard to emulsify. Viability is lost rapidly after 7 days on $\mathrm{MA}$ at $30^{\circ} \mathrm{C}$. Reduces nitrate to nitrite. Decomposes DNA, 
Table 2. Cellular fatty acid composition (\%) of strains $\mathrm{JC} 2042^{\top}$ and $\mathrm{JC} 2043^{\top}$

Only fatty acids that represent $\geqslant 1 \%$ of the total fatty acids of at least one of the strains are shown.

\begin{tabular}{|c|c|c|}
\hline Fatty acid & $\mathrm{JC} 2042^{\mathrm{T}}$ & $\mathrm{JC2043}{ }^{\mathrm{T}}$ \\
\hline $\mathrm{C}_{10: 0} 3-\mathrm{OH}$ & $0 \cdot 6$ & $4 \cdot 6$ \\
\hline $\mathrm{C}_{12: 0}$ & $1 \cdot 8$ & $3 \cdot 0$ \\
\hline $\mathrm{C}_{11: 0} 3-\mathrm{OH}$ & $1 \cdot 0$ & $0 \cdot 3$ \\
\hline $\mathrm{C}_{12: 1} 3-\mathrm{OH}$ & $2 \cdot 2$ & $1 \cdot 1$ \\
\hline $\mathrm{C}_{12: 0} 3-\mathrm{OH}$ & $1 \cdot 0$ & $0 \cdot 6$ \\
\hline $\mathrm{C}_{14: 0}$ & $3 \cdot 9$ & $3 \cdot 1$ \\
\hline $\mathrm{C}_{15: 1} \omega 8 c$ & $1 \cdot 0$ & $0 \cdot 5$ \\
\hline $\mathrm{C}_{15: 0}$ & $3 \cdot 8$ & $2 \cdot 4$ \\
\hline $\mathrm{C}_{16: 1} \omega 7 c$ alcohol & $2 \cdot 1$ & $0 \cdot 7$ \\
\hline $\begin{array}{l}\text { Sum } 2^{*}\left(\mathrm{C}_{12: 0} \text { alde/iso- } \mathrm{C}_{16: 1}\right. \\
\left.\mathrm{I} / \mathrm{C}_{14: 0} 3-\mathrm{OH}\right)\end{array}$ & $2 \cdot 0$ & $1 \cdot 6$ \\
\hline iso- $\mathrm{C}_{16: 0}$ & $1 \cdot 1$ & $0 \cdot 1$ \\
\hline $\begin{array}{l}\text { Sum } 3^{\star}\left(\mathrm{C}_{16: 1} \omega 7 c / \text { iso- } \mathrm{C}_{15: 0}\right. \\
2-\mathrm{OH})\end{array}$ & $27 \cdot 2$ & $32 \cdot 5$ \\
\hline $\mathrm{C}_{16: 0}$ & $15 \cdot 8$ & $23 \cdot 9$ \\
\hline iso- $\mathrm{C}_{17: 1} \omega 5 c$ & $0 \cdot 0$ & $1 \cdot 6$ \\
\hline $\mathrm{C}_{17: 1} \omega 8 c$ & $6 \cdot 8$ & $3 \cdot 1$ \\
\hline $\mathrm{C}_{17: 0}$ & $4 \cdot 5$ & $2 \cdot 8$ \\
\hline $\mathrm{C}_{18: 1} \omega 7 c$ & $14 \cdot 0$ & $11 \cdot 1$ \\
\hline $\mathrm{C}_{18: 0}$ & $2 \cdot 9$ & $0 \cdot 9$ \\
\hline $\begin{array}{l}\text { Sum } 7^{\star}\left(\mathrm{C}_{19: 1} \omega 6 c / \mathrm{C}_{19: 0} \omega 10 c\right. \\
\left.\text { cyclo/ } \mathrm{C}_{19: 0} \omega 6 c\right)\end{array}$ & $1 \cdot 1$ & $0 \cdot 3$ \\
\hline
\end{tabular}

*Sum, summed features (groups of two or three fatty acids that could not be separated by GLC with the MIDI system).

aesculin, gelatin, starch and Tween 80 , but not agar, alginate, casein, cellulose, chitin or egg yolk. Does not produce arginine dihydrolase, $\beta$-galactosidase, fluorescein, $\mathrm{H}_{2} \mathrm{~S}$, indole, polyhydroxybutyrate or urease. Does not ferment carbohydrates. Produces alkaline phosphatase, esterase (C4), esterase lipase (C8), leucine arylamidase, trypsin and naphthol-AS-BI-phosphohydrolase, but not lipase (C14), valine arylamidase, cystine arylamidase, $\alpha$-chymotrypsin, acid phosphatase, $\alpha$-galactosidase, $\beta$-galactosidase, $\beta$ glucuronidase, $\alpha$-glucosidase, $\beta$-glucosidase, $N$-acetyl- $\beta$ glucosaminidase, $\alpha$-mannosidase or $\alpha$-fucosidase. Utilizes acetate, glycine, inulin, L-arginine, L-ornithine and $\mathrm{N}$ acetylglucosamine as sole carbon sources. D-Galactose, D-ribose, D-sorbitol, ethanol, L-lysine and succinate are utilized weakly. Does not utilize acetamide, adenine, benzoate, citrate, D-cellobiose, D-fructose, D-glucose, D-mannose, D-raffinose, D-salicin, D-xylose, inositol, 2-propanol, lactose, L-cysteine, L-rhamnose, sucrose, salicylate or thiamin. Cellular fatty acid composition is given in Table 2. DNA G $+\mathrm{C}$ content is $48 \mathrm{~mol} \%$.

The type strain is $\mathrm{JC}^{2} 042^{\mathrm{T}}\left(=\mathrm{IMSNU} 14006^{\mathrm{T}}=\mathrm{KCTC}\right.$ $\left.12042^{\mathrm{T}}=\mathrm{DSM} 15300^{\mathrm{T}}\right)$. Isolated from the sediment of getbol, the Korean tidal flat.

\section{Description of Aestuariibacter halophilus sp. nov.}

Aestuariibacter halophilus (ha.lo' phi.lus. Gr. n. hals halos salt; Gr. adj. philos loving; N.L. masc. adj. halophilus salt-loving).

Cells are approximately $1 \cdot 2-1 \cdot 8 \mu \mathrm{m}$ long and $0 \cdot 5-0 \cdot 6 \mu \mathrm{m}$ wide. Optimal growth is observed at $40^{\circ} \mathrm{C}, \mathrm{pH} 7-8$ and $2-3 \%$ artificial sea salts. Colonies are circular, convex, entirely margined, butyraceous, glistening, opaque and white on MA. Reduces nitrate to nitrite. Decomposes casein, DNA, egg yolk, aesculin, gelatin, starch and Tween 80 , but not agar, alginate, cellulose or chitin. Does not produce arginine dihydrolase, $\beta$-galactosidase, fluorescein, $\mathrm{H}_{2} \mathrm{~S}$, indole, polyhydroxybutyrate or urease. Does not ferment carbohydrates. Produces alkaline phosphatase, esterase (C4), esterase lipase (C8), leucine arylamidase, trypsin, acid phosphatase, naphthol-AS-BI-phosphohydrolase and $\beta$-glucosidase, but not lipase (C14), valine arylamidase, cystine arylamidase, $\alpha$-chymotrypsin, $\alpha$-galactosidase, $\beta$-galactosidase, $\beta$-glucuronidase, $\alpha$-glucosidase, $N$-acetyl$\beta$-glucosaminidase, $\alpha$-mannosidase or $\alpha$-fucosidase. Utilizes acetate, D-glucose, D-ribose, L-arginine, $\mathrm{N}$-acetylglucosamine and sucrose as sole carbon sources. Does not utilize acetamide, adenine, benzoate, citrate, D-cellobiose, D-fructose, D-galactose, D-mannose, D-raffinose, D-salicin, D-sorbitol, D-xylose, ethanol, glycine, inositol, inulin, 2-propanol, lactose, L-cysteine, L-lysine, L-ornithine, L-rhamnose, salicylate, succinate or thiamin. Cellular fatty acid composition is given in Table 2. DNA G $+\mathrm{C}$ content is $54 \mathrm{~mol} \%$.

The type strain is $\mathrm{JC} 2043^{\mathrm{T}}\left(=\mathrm{IMSNU} 14007^{\mathrm{T}}=\mathrm{KCTC}\right.$ $\left.12043^{\mathrm{T}}=\mathrm{DSM} 15266^{\mathrm{T}}\right)$. Isolated from the sediment of getbol, the Korean tidal flat.

\section{Emended description of Alteromonas macleodii}

The description remains as those given by Baumann et al. (1972, 1984) and Gauthier et al. (1995), with the following modification: positive for catalase reaction. The following is added to the descriptions of Baumann et al. $(1972,1984)$ and Gauthier et al. (1995). Major isoprenoid quinone is ubiquinone-8. Positive for $\beta$-galactosidase, aesculinase and lecithinase. Negative for urease, caseinase and cellulase. Does not produce indole. Utilizes D-raffinose, D-ribose, L-arginine and succinate as sole carbon sources, but not D-sorbitol or thiamin. Produces alkaline phosphatase, esterase (C4), esterase lipase (C8), leucine arylamidase, valine arylamidase, acid phosphatase and naphthol-AS-BIphosphohydrolase, but not lipase (C14), cystine arylamidase, trypsin, $\alpha$-chymotrypsin, $\alpha$-galactosidase, $\beta$-galactosidase, $\beta$-glucuronidase, $\alpha$-glucosidase, $\beta$-glucosidase, $N$-acetyl- $\beta$ glucosaminidase, $\alpha$-mannosidase or $\alpha$-fucosidase.

\section{ACKNOWLEDGEMENTS}

We are grateful to J. P. Euzéby for help with nomenclature. This work was supported by the $21 \mathrm{C}$ Frontier Microbial Genomics and 
Applications Center Program, Ministry of Science and Technology (grant MG02-0101-001-2-1-0), Republic of Korea. H. Y. was supported by a Brain Korea 21 Research Fellowship.

\section{REFERENCES}

Baumann, P., Baumann, L. \& Mandel, M. (1971). Taxonomy of marine bacteria: the genus Beneckea. J Bacteriol 107, 268-294.

Baumann, L., Baumann, P., Mandel, M. \& Allen, R. D. (1972). Taxonomy of aerobic marine eubacteria. J Bacteriol 110, 402-429.

Baumann, P., Baumann, L., Bowditch, R. D. \& Beaman, B. (1984). Taxonomy of Alteromonas: A. nigrifaciens sp. nov., nom. rev.; A. macleodii; and A. haloplanktis. Int J Syst Bacteriol 34, 145-149.

Bowman, J. P., McCammon, S. A., Brown, J. L. \& McMeekin, T. A. (1998). Glaciecola punicea gen. nov., sp. nov. and Glaciecola pallidula gen. nov., sp. nov.: psychrophilic bacteria from Antarctic sea-ice habitats. Int J Syst Bacteriol 48, 1213-1222.

Chun, J. \& Goodfellow, M. (1995). A phylogenetic analysis of the genus Nocardia with $16 \mathrm{~S}$ rRNA gene sequences. Int J Syst Bacteriol 45, 240-245.

Chun, J., Bae, K. S., Moon, E. Y., Jung, S.-O., Lee, H. K. \& Kim, S.-J. (2000). Nocardiopsis kunsanensis sp. nov., a moderately halophilic actinomycete isolated from a saltern. Int J Syst Evol Microbiol 50, 1909-1913.

Collins, M. D. (1985). Analysis of isoprenoid quinones. Methods Microbiol 18, 329-366.

Felsenstein, J. (1985). Confidence limits on phylogenies: an approach using the bootstrap. Evolution 39, 783-791.

Felsenstein, J. (1993). PHYLIP (phylogeny inference package), version 3.5c. Department of Genetics, University of Washington, Seattle, USA.

Fitch, W. M. (1971). Toward defining the course of evolution: minimum change for a specific tree topology. Syst Zool 20, 406-416.

Fitch, W. M. \& Margoliash, E. (1967). Construction of phylogenetic trees. Science 155, 279-284.

Gauthier, G., Gauthier, M. \& Christen, R. (1995). Phylogenetic analysis of the genera Alteromonas, Shewanella, and Moritella using genes coding for small-subunit rRNA sequences and division of the genus Alteromonas into two genera, Alteromonas (emended) and Pseudoalteromonas gen. nov., and proposal of twelve new species combinations. Int J Syst Bacteriol 45, 755-761.

Ivanova, E. P. \& Mikhailov, V. V. (2001). A new family, Alteromonadaceae fam. nov., including marine proteobacteria of the genera Alteromonas, Pseudoalteromonas, Idiomarina, and Colwellia. Mikrobiologiya 70, 15-23 (in Russian).
Jukes, T. H. \& Cantor, C. R. (1969). Evolution of protein molecules. In Mammalian Protein Metabolism, pp. 21-132. Edited by H. N. Munro. New York: Academic Press.

Leifson, E. (1963). Determination of carbohydrate metabolism of marine bacteria. J Bacteriol 85, 1183-1184.

Lyman, J. \& Fleming, R. H. (1940). Composition of sea water. J Mar Res 3, 134-146.

Macián, M. C., Ludwig, W., Schleifer, K. H., Garay, E. \& Pujalte, M. J. (2001). Thalassomonas viridans gen. nov., sp. nov., a novel marine $\gamma$-proteobacterium. Int J Syst Evol Microbiol 51, 1283-1289.

Mesbah, M., Premachandran, U. \& Whitman, W. B. (1989). Precise measurement of the $\mathrm{G}+\mathrm{C}$ content of deoxyribonucleic acid by high-performance liquid chromatography. Int J Syst Bacteriol 39, 159-167.

Mikhailov, V. V., Romanenko, L. A. \& Ivanova, E. P. (2002). The Genus Alteromonas and related Proteobacteria. In The Prokaryotes: an Evolving Electronic Resource for the Microbiological Community. Edited by M. Dworkin, S. Falkow, E. Rosenberg, K. H. Schleifer \& E. Stackebrandt. New York: Springer.

Minnikin, D. E., O'Donnell, A. G., Goodfellow, M., Alderson, G., Athayle, M., Schaal, A. \& Parlett, J. H. (1984). An integrated procedure for the extraction of isoprenoid quinones and polar lipids. J Microbiol Methods 2, 233-241.

Saitou, N. \& Nei, M. (1987). The neighbor-joining method: a new method for reconstructing phylogenetic trees. Mol Biol Evol 4, 406-425.

Sawabe, T., Makino, H., Tatsumi, M., Nakano, K., Tajima, K., Iqbal, M. M., Yumoto, I., Ezura, Y. \& Christen, R. (1998). Pseudoalteromonas bacteriolytica sp. nov., a marine bacterium that is the causative agent of red spot disease of Laminaria japonica. Int J Syst Bacteriol 48, 769-774.

Shiba, T. (1981). The genus Roseobacter. In The Prokaryotes: A Handbook on Habitats, Isolation and Identification of Bacteria. Edited by A. Balows, H. G. Trüper, M. Dworkin, W. Harder \& K. H. Schleifer. Berlin: Springer-Verlag.

Stackebrandt, E. \& Goebel, B. M. (1994). Taxonomic note: a place for DNA-DNA reassociation and 16S rRNA sequence analysis in the present species definition in bacteriology. Int J Syst Bacteriol 44, 846-849.

Swofford, D. L. (1998). PAUP: Phylogenetic analysis using parsimony, version 4. Sunderland, MA: Sinauer Associates.

Yi, H., Chang, Y.-H., Oh, H. W., Bae, K. S. \& Chun, J. (2003). Zooshikella ganghwensis gen. nov., sp. nov., isolated from tidal flat sediments. Int J Syst Evol Microbiol 53, 1013-1018.

Yoon, J.-H., Kim, I.-G., Kang, K. H., Oh, T.-K. \& Park, Y.-H. (2003). Alteromonas marina sp. nov., isolated from sea water of the East Sea in Korea. Int J Syst Evol Microbiol 53, 1625-1630. 